\title{
Research on the Course Reform of Employee Career Planning and Management
}

\author{
Fengxiang Jiang ${ }^{1, *}$, Fang Wang ${ }^{1}$, Moutao $\mathrm{Du}^{1}$, Sisi Wang ${ }^{1}$, Chen Wang ${ }^{1}$ and Junjie \\ $\operatorname{Lin}^{1}$
}

${ }^{1}$ College of Accounting and Finance, Xi'an Peihua University, Xi'an, Shaanxi 710125, China

*Corresponding author. Email: 150496@peihua.edu.cn

\begin{abstract}
Employee Career Planning and Management is one of the professional courses of the major in Human Resource Management. This course helps students improve their organizational ability and facilitate their employment. Only by strengthening the reform and innovation of the course can we achieve its goals. This article used a variety of research methods such as literature review, interview, personal experience, and case analysis. The paper puts forward the objectives of the course reform, reconstructs its content system, and establishes its implementation process to achieve the knowledge goals, skills goals and emotional goals of the course to help students become talented adults.
\end{abstract}

Keywords: Employee Career Planning and Management, Course Reform, Course Innovation

\section{INTRODUCTION}

With the continuous emergence of new teaching methods and technologies such as MOOCs, Micro-classes and Flipped Classrooms and so on, teacher-led teaching mode, a traditional teaching model, needs to be transformed into student-oriented model, which is a teaching mode that students play the main role in the implementation of the course of Employee Career Planning and Management. The course of Employee Career Planning and Management is a highly applicable course[1]. It is necessary and important to carry out the course reform of Employee Career Planning and Management, to strengthen the combination of theory and practice. The course of Employee Career Planning and Management requires students not only to have a multi-faceted, global system of knowledge, but also it trains students to use knowledge to analyze specific cases. Therefore, the course of Employee Career Planning and Management should pay attention to the use of Internet technology and platforms to obtain multi-perspective and diversified teaching resources, and build a case-oriented interactive teaching model based on flipped classrooms. This article mainly explores ideas of the course reform of Employee Career Planning and Management. The paper researches the thoughts of the course reform of Employee Career Planning and Management from the teaching concept, teaching mode, teaching methods, teaching resources, teaching team and other aspects.

\section{THE NECESSITY AND IMPORTANCE OF THE COURSE REFORM OF EMPLOYEE CAREER PLANNING AND MANAGEMENT}

\subsection{To improve the quality of courses through teaching reforms}

The Ministry of Education issued the Notice on Paying Close Attention to the Implementation of the Spirit of the National Undergraduate Education Work Conference in the New Era in August 2019. The Golden course was written into the Ministry of Education document for the first time. The Notice requires all colleges and universities to comprehensively sort out each subject. The teaching content of the course is to eliminate Water Courses and create Golden Courses to effectively improve the quality of courses. Water Courses mean the quality of the courses is not good. Golden Courses mean the quality of the courses is good. The course of Employee Career Planning and Management needs to keep pace with the times, adopting student-oriented teaching methods, changing learning styles, exploring innovative ideas for the development of smart teaching and innovative application of new models, to improve the quality of courses, to gain the talent training objectives and help the overall improvement of the quality of higher education[2]. 


\subsection{To achieve better course teaching goals}

This course reform of Employee Career Planning and Management should adhere to employment-oriented and student-oriented, taking project tasks as the carrier and comprehensive development as the goal, guiding students to establish correct career concepts and career ideals, and possessing own ability of self-career planning and development, and conduct career channel design and career goal management for employees from the organization level[3]. According to the construction standards of first-class course for mixed teaching, it is necessary to strengthen the scientific management team of the Employee Career Planning and Management, strengthen cooperative teaching and build research team, build rich course resources, increase cooperation with external resources, give full play to the dominant position of students, and establish mutual learning among students groups and so on.

\section{THE CURRENT SITUATION AND PROBLEMS OF THE COURSE OF EMPLOYEE CAREER PLANNING AND MANAGEMENT}

\subsection{The current situation of the course of Employee Career Planning and Management}

The course of Employee Career Planning and Management is a professional course for the major of Human Resource Management. There are relatively few colleges and universities offering this course. Students studying Human resource management need to master personal and organizational career planning and management through this course. The goals of the course are to make students master the knowledge and skills of career planning and management through learning the content of the course[4]. The specific content of the course is shown in Table 1:

Table 1 Summary of the course on Employee Career Planning and Management

\begin{tabular}{|c|c|}
\hline Modules of Course & Content of Course \\
\hline $\begin{array}{l}\text { Module 1: What is Employee career } \\
\text { planning? }\end{array}$ & $\begin{array}{l}\text { 1.Terms of the Course: Posts, position, occupation } \\
\text { 2. What is a career? } \\
\text { 3. What is employee career planning? } \\
\text { 4. What is employee career management? }\end{array}$ \\
\hline Module 2: Why do you plan your career? & $\begin{array}{l}\text { 1. Needs of Employee. } \\
\text { 2. Needs of organization. }\end{array}$ \\
\hline $\begin{array}{l}\text { Module 3: Roles and Tasks in Employee } \\
\text { Career Planning }\end{array}$ & $\begin{array}{l}\text { 1. Respective roles of individual employees, line managers, and human } \\
\text { resources department } \\
\text { 2.Tasks of Individual employee, line manager, human resources } \\
\text { department }\end{array}$ \\
\hline Module 4: Analysis of Career Planning Route & $\begin{array}{l}\text { 1. Analysis chart of employee career planning route } \\
\text { 2. Analysis window of employee career planning route } \\
\text { 3. SWOT analysis method } \\
\text { 4. } 5 \text { P' Principles of Employee Career Planning } \\
\text { 5. The basis of employee' career planning }\end{array}$ \\
\hline Module 5: Career Development Channel & $\begin{array}{l}\text { 1. } 4 \text { channels of employee career development } \\
\text { 2. Career development of employees should be carried out within the } \\
\text { framework of the organizational structure of the enterprise }\end{array}$ \\
\hline $\begin{array}{l}\text { Module 6: Process of Employee Career } \\
\text { Planning }\end{array}$ & $\begin{array}{l}\text { 1.Flow chart of Employee career planning } \\
\text { 2. Cases: Employee career planning tables } \\
\text { 3. Cases: Employee transfer systems and processes } \\
\text { 4. Cases: Employee promotion systems and processes }\end{array}$ \\
\hline $\begin{array}{l}\text { Module 7: Organizational and Personal Issues } \\
\text { and Analysis of Employee Career Planning }\end{array}$ & $\begin{array}{l}\text { 1. Does need career planning for all companies } \\
\text { 2. Do all employees need to do career planning } \\
\text { 3. Does employee expect to deviate from the actual situation } \\
\text { 4. Whether the enterprise can fulfill the promise of employee career } \\
\text { planning } \\
\text { 5. The sustainability of employee career planning and management } \\
6 \text {. Employee' personal career planning }\end{array}$ \\
\hline
\end{tabular}




\subsection{The problems of the course of Employee Career Planning and Management}

Colleges and universities that set up the course of Employee Career Planning and Management have an insufficient investment in course construction, lack of effective construction mechanisms for this course, insufficient teaching team construction of the course, and relatively few related teaching results and no high-quality course resources. This course mainly uses traditional teaching models and methods, which is difficult to improve students' interest and enthusiasm for learning[5].

\section{INFLUENCING FACTORS OF THE COURSE REFORM OF EMPLOYEE CAREER PLANNING AND MANAGEMENT}

There are many influencing factors in the course reform of Employee Career Planning and Management[6]. The influencing factors mainly analyzed in this article include course team, course resources, teaching mode, and funding input and so on.

\subsection{Course team}

The course reform of Employee Career Planning and Management requires an excellent course team; the course team gathers the views and experiences of members through team discussions, and uses knowledge integration mechanisms to achieve course knowledge integration. The course team of Employee Career Planning and Management should formulate course reform goals, carry out knowledge sharing, conceptual discussions and construct new knowledge around the course reform goals to form a unified teaching material, including relevant course opening instructions, teaching plans, syllabus, lecture notes (teaching plans), case library, exercise library, etc.

\subsection{Course resources}

With the influence of Internet technology on education, the course of Employee Career Planning and Management needs to keep pace with the times to make full use of Internet technology and platforms to construct and enrich online course resources, and realize that students can obtain the course resource before, during and after class[7]. When it comes to learning resources, it can improve students' initiative, interest and enthusiasm in learning. Construction of the course resource is very important for course reform. It is necessary and important to strengthen construction of course resource, especially online teaching resources. It is important o strengthen the value, efficiency, experience and relevance of construction course resources[8].

\subsection{Teaching mode}

The course of Employee Career Planning and Management is a highly applied course[9]. Therefore, the reform of the course needs to focus on cultivating students' ability to analyze and solve practical problems. Strengthening the practical teaching system is to cultivate students' innovation and cooperation ability. Therefore, the course reform of Employee Career Planning and Management should focus on the reconstruction of the teaching system. Students should be involved, experienced, and practiced, familiar with the basic theories of employee career combine human resource development, grasp the career cycle, and formulate career plans.

\subsection{Funding}

The course of Employee Career Planning and Management need a professional course teaching team, who contains mentors from corporates and the teachers, and the teaching team need have professionals who do career planning for the corporate to join the course construction; it is necessary and important to establish a practical teaching base, in which students can observe the corporate, and interview corporate personnel; it is necessary to strengthen the informatization construction of the course of Employee Career Planning and Management and strengthen the construction of online resources. What to do for the course requires a lot of manpower, material and financial resources. Therefore, colleges and universities should pay attention to the funding input of the course reform of the Employee Career Planning and Management, to ensure the implementation of the course reform.

\section{THOUGHTS ON THE REFORM OF EMPLOYEE CAREER PLANNING AND MANAGEMENT COURSE}

\subsection{To clear teaching goals}

The application undergraduate colleges and universities are in the process of transformation, to train the talented person with application skill. The major of human resource management needs to be positioned in accordance with needs, and needs to closely follow the training goals of applied talents, speed up course reform, and cultivate the professional ability, method ability and employment ability of students.

Professional ability contains cultivating students' ability of self-cognition, career environment analysis, career goal planning, career decision-making, career planning and management, feedback, evaluation, correction, etc.

Method ability contains various self-cognition tests, career environment analysis methods, career decision-making methods, SWOT analysis methods, CASVE cycle method, 
career decision-making balance method, career goal determination method, etc.

Social ability contains improving students' ability to evaluate and understand them objectively, correctly using professional environment analysis methods, flexibly set career goals, making accurate career decisions, and the abilitt that students can organize career planning methods and master management measures, etc.

\subsection{To innovative teaching mode}

The traditional offline teaching will be changed to a hybrid teaching mode, combining online + offline, to build a flipped classroom mode, focusing on exploration and experience of the students, many application scenarios for earning credit have been created, including the creation of a virtual corporation, to help students know and design the organizational structure and corporate publicity[10]; students need to finish team case and give lectures; students need to plan classroom activities to increase participatory and learning interest; students need to set up Employee birthday banquets and year-end summary meetings according to work scenes; students need to build groups of students of different grades in the major of Human Resource, who give gifts, share hot spots, and become good friends; the students need to help others with psychological counseling, to help others study courses, career planning; the students need to thank their teachers through I Want to Say to Teacher, etc. All that the students do is to improve the communication skill and their EQ. It is important to establish the public account of the Workplace Fulcrum, and establish the exchange of opinions before and after class through WeChat; the students and the teachers need to communicate through the platform of LanMo Cloud Classroom.

\subsection{To reform teaching methods}

It is important to emphasize the subjectivity adhere to the student-oriented, and stimulate the exploration spirit of students, emphasizing the sense of experience. Students respect their own fruits of labor, listen to their own initiative in class, and actively display in class, emphasis on team spirit. All learning tasks must be completed by the team, discuss with each other, enhance communication and interaction between students, and enhance the sense of collective honor, paying attention to practical application and combine the competence requirements of positions of human resource management to construct various scenarios. Students can plan, arrange, execute and evaluate the effects of activities according to the theme deployed by the teacher, comprehensive application of teaching methods such as traditional teaching methods, group discussion method, virtual situation method, situation experience method, management game method, etc., to enhance students' initiative, enthusiasm and creativity in learning, combining case analysis method, scenario simulation method, virtual scenario experience method, flipped classroom, and interactive teaching method, which can improve students' understanding of professional knowledge. The methods of the course are shown in Fig. 1:

Traditional teaching methods

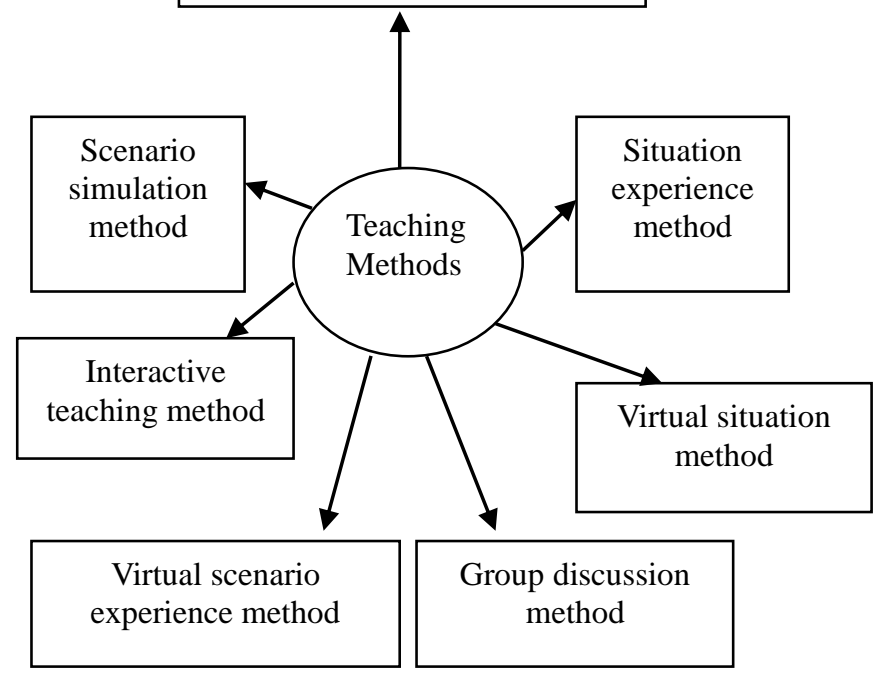

Figure 1. Teaching methods

\subsection{To enrich teaching tasks}

Teaching should not just stay in the classroom, but runs through the pre-class, after-class, and during the class. The teachers issue learning tasks to students through the course discussion group pre-class. The tasks that students complete include reading news, reading literature, writing papers, planning activities, design questionnaires, participate in research, situational simulation, video shooting, team building, etc. The seat group arrangement is different for each class in the class, and there are triangles, rectangles, u-shaped, round, back-shaped, L-shaped, etc. The interaction between teachers and students is diverse and various: knowledge contests, debate questions, management games, role-playing, etc. It is necessary and important to complete case collection and course content reflection after class. Students need to finish many tasks to improve several of their abilities.

\subsection{To construct teaching resources}

It is necessary and important to establish a practical teaching base, in which students observe the corporate, and interview corporate personnel to understand some of the current statuses of employee career planning and management; it is important to establish a course teaching team, which includes introduced corporate mentors, and professionals who do career planning for the corporate to join the course construction. It is important to improve all kinds of teaching resources of the Employee Career 
Planning and Management, to build more resources for off-campus cooperative enterprises; it is necessary to establish offline course research and development teams, to develop course resources; to establish an online resource library, including cases, exercises, some other information, etc. We will explore the online course of Employee Career Planning and Management and record some micro-class courses, to strengthen the information construction of the course of Employee Career Planning and Management to improve students' self-learning spirit and self-learning ability and add the course network discussion community, class official account, and course resource. It is required that the teachers use information teaching platforms to management, such as the Lan Mo Cloud Classroom and so on. It is necessary and important to build network resources for the course of Employee Career Planning and Management, including high-quality course videos, case base, academic topics, course exercises, course assignments, online examinations of the course and so on.

\section{CONCLUSION}

All in all, the course reform of Employee Career Planning and Management needs to increase students' interest in learning and stimulate students' learning passion, focus on student participation and improve students' sense of learning experience, to make full use of the Internet, establishing online teaching materials, and form online + offline mode of teaching. We will continue to enrich the teaching resources of the course of Employee Career Planning and Management, strengthen the docking of external resources, and realize the teaching reform goals of the course of Employee Career Planning and Management.

\section{ACKNOWLEDGMENT}

Xi'an Peihua University School-level Applied Demonstration Course in 2020, Name of the course: Employee Career Planning and Management

\section{REFERENCES}

[1] Zhao Wenjin. Exploration and Practice of the Reconstruction of the Teaching System of Employee Career Planning and Management [J]. Contemporary Educational Practice and Teaching Research (Electronic Edition), 2016.
[2] Zhang Jiemei. Analysis of University Management Course Team Learning Based on Knowledge Integration [J]. Market Weekly (Theoretical Research), 2013(8): pp. 22-23.

[3] Zhao Limei, Sun Yanhua, Liu Yanfang. Research on the Internal Knowledge Integration Process of Scientific Research Teams in Colleges and Universities Based on the Behavioral Knowledge Information Fusion Model[J]. Science and Technology Progress and Policy, 2014(21): pp. 125-132.

[4] Yuan Xi. The Reform and Practice of Management Courses in Higher Vocational Colleges Based on the PDCA Cycle Theory[J]. Journal of Liaoning College of Transportation, 2019, 021(005): pp. 75-79.

[5] Wang Shuqing. Research on the Reform and Construction of the Economic Law Course for Business Administration Based on the Perspective of MOOC[J]. Time People, 2019(10): pp. 82-83.

[6] Du Lihong and Hu Chuan. Research on Case Teaching of Management Courses based on MOOC and Flipped Classroom[J]. Higher Education Review, 2017, 000(002): pp. 186-194.

[7] Li Zhanqiang. Flipped Classroom Teaching Research Based on MOOC and Open Cases-Taking the Course Strategic Management as an example [J]. Teaching Research, 2019, 42(01): pp. 75-81.

[8] Liao Yuanqing and Wang Xiaoping. Research on Teaching Reform of System Simulation Course Based on Cultivation of Innovation Ability [J]. Education Teaching Forum, 2013, 000(010): pp. 55-56.

[9] Lu Fangwei. Application of Personal and Organizational Matching in the Career Management of Employees [J]. Journal of Jiangsu Institute of Engineering and Technology, 2018, 018(001): pp.51-54.

[10] Guan Yaling. Brief Discussion of the Situation of Career Planning and Career Management of the Enterprises and Their Employees [J]. Business, 2019000(045): pp. 118-119. 